\title{
Empirical Models for Estimating Global Solar Radiation over the Ashanti Region of Ghana
}

\author{
Emmanuel Quansah, Leonard K. Amekudzi, Kwasi Preko, Jeffrey Aryee, Osei R. Boakye, \\ Dziewornu Boli, and Mubarick R. Salifu
}

Department of Physics, Kwame Nkrumah University of Science and Technology, Kumasi, Ghana

Correspondence should be addressed to Emmanuel Quansah; ekq_2@yahoo.com

Received 28 August 2013; Revised 19 November 2013; Accepted 20 November 2013; Published 16 January 2014

Academic Editor: Xin Wang

Copyright (C) 2014 Emmanuel Quansah et al. This is an open access article distributed under the Creative Commons Attribution License, which permits unrestricted use, distribution, and reproduction in any medium, provided the original work is properly cited.

\begin{abstract}
The performances of both sunshine and air temperature dependent models for the estimation of global solar radiation (GSR) over Ghana and other tropical regions were evaluated and a comparison assessment of the models was carried out using measured GSR at Owabi $\left(6^{\circ} 45^{\prime} 0^{\prime \prime} \mathrm{N}, 1^{\circ} 43^{\prime} 0^{\prime \prime} \mathrm{W}\right)$ in the Ashanti region of Ghana. Furthermore, an empirical model which also uses sunshine hours and air temperature measurements from the study site and its environs was proposed. The results showed that all the models could predict very well the pattern of the measured monthly daily mean GSR for the entire period of the study. However, most of the selected models overestimated the measured GSR, except in April and November, where the empirical model using air temperature measurements underestimated the measured GSR. Nevertheless, a very good agreement was found between the measured radiations and the proposed models with a coefficient of determination within the range $0.88-0.96$. The results revealed that the proposed models using sunshine hours and air temperature had the smallest values of MBE, MPE, and RMSE of -0.0102, 0.0585 , and 0.0338 and $-0.2973,1.7075$, and 0.9859 , respectively.
\end{abstract}

\section{Introduction}

Solar radiation is the primary source of the Earth's energy, providing about $99.97 \%$ of the heat energy required for chemophysical processes in the atmosphere, ocean, land, and other water bodies [1]. Solar radiation plays an important role as a renewable energy source as solar radiation measurements could be used to estimate potential power levels that can be generated from photovoltaic cells and also necessary for determining cooling loads for buildings [2]. Solar radiation thus has many useful applications in architectural design, evapotranspiration estimates, agriculture, and atmospheric, land, ocean, and hydrologic models $[3,4]$. The acquisition and the development of database on the long term solar radiation will facilitate the evaluation of solar energy potential as an input to the country's energy budget and other modeling applications mentioned earlier. The development of solar technology in the country will minimise its overreliance on wood fuel consumption, estimated at 18 million tons per annum, especially in the rural communities ([5] and references therein). Studies carried out on solar irradiance measurements in some parts of the country suggest that there is a potential for solar energy to be used on commercial scale and in this vein the Ghana Grid Company (GRIDco) has begun producing electrical energy from a solar farm established in the northern part of Ghana [6-8].

The immediate short term to the long term solutions to address the problems of inadequate infrastructure in the area of solar energy data acquisitions have been the application of empirical models that rely on the correlation between the parameters obtained from measured meteorological data $[4,9]$. In this regard, several empirical formulae have been developed to predict the global solar radiation using various meteorological variables such as sunshine hours, cloud cover, relative humidity, maximum temperature, and water vapour pressure [4, 9-12]. However, the reliability and usability of these models depend largely on the strength of the correlation between the estimated and measured variables. 


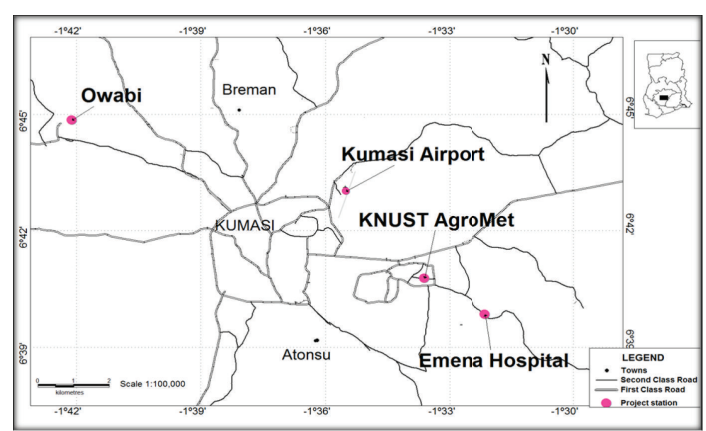

FIGURE 1: Locations of the KNUST surface observation sites in the Ashanti region of Ghana.

The aim of this paper is to assess the suitability of both sunshine and temperature dependent empirical models for the estimation of global solar radiation in Ghana.

\section{Materials and Methods}

The measurement of the hourly global solar radiation was carried out at Owabi, in the Ashanti region of Ghana, $6.750^{\circ} \mathrm{N}, 1.716^{\circ} \mathrm{W}$ and $77 \mathrm{~m}$ asl. The site is located near the Owabi dam surrounded by forest (see Figure 1). In this paper, data analysed span between the months of February and December 2011. The global solar radiation data was measured with a pyranometer, with a spectral range between 5 and $42 \mu \mathrm{m}$. The pyranometer was mounted on an automatic weather station that also provided data on temperature, relative humidity, atmospheric pressure, rainfall, downwelling radiation, soil matrix potential, soil heat flux, and wind speed in horizontal and vertical directions. The sunshine hours data was obtained from the synoptic station of the Ghana Meteorological Agency, at the Kumasi airport, about $20 \mathrm{~km}$ from the study site. The air temperature data used to calculate the global solar radiation was measured on site using the ventilation resistant thermometers placed $2 \mathrm{~m}$ above the ground. All the data used in this paper had been taken through quality checks and controls using methods explained by Allen et al. [15].

2.1. Empirical Model Based on Sunshine Hours. Most empirical models used to predict global solar radiation are based on the Angstrom-Prescott model [16], given as

$$
\frac{G_{p}}{G_{o}}=a+b\left(\frac{n}{N}\right)
$$

where $G_{p}\left(\mathrm{MJ} \mathrm{m}^{-2}\right.$ day $\left.^{-1}\right)$ is the predicted monthly mean of daily global solar radiation on a horizontal surface, $G_{o}$ $\left(\mathrm{MJ} \mathrm{m}^{-2}\right.$ day $\left.^{-1}\right)$ is the monthly mean extraterrestrial solar radiation on horizontal surface, $n$ is the monthly mean daily number of hours of sunshine, and $N$ is the maximum monthly mean daily sunshine $\left(\mathrm{MJ} \mathrm{m}^{-2} \mathrm{day}^{-1}\right)$. The constants $a$ and $b$ are the location specific empirical coefficients, obtained from measured solar radiation data. The monthly average daily extraterrestrial irradiance $G_{o}\left(\mathrm{KWh} \mathrm{m}^{-2}\right.$ day $\left.^{-1}\right)$ is estimated using

$$
G_{o}=\frac{24 \times 3600}{\pi} I_{o}\left(\frac{\pi}{180} \omega_{s} \sin \varphi \sin \delta+\cos \varphi \sin \omega_{s}\right),
$$

where $I_{o}$ is the solar constant $\left(1367 \mathrm{~W} \mathrm{~m}^{-2}\right), \varphi$ is latitude (degree), $\delta$ is the solar declination for the month (degree), and $\omega_{s}$ is the mean sunrise hour angle for the given month (degree). The values of $\delta$ and $\omega_{s}$ can be calculated using (3) and (4), respectively, where all the parameters have their usual meanings and $k$ is the Julian days starting from 1st of January:

$$
\begin{gathered}
\delta=23.45 \sin \left[\frac{360(k+284)}{365}\right], \\
\omega_{s}=\cos ^{-1}(-\tan \varphi \tan \delta) .
\end{gathered}
$$

The units in $\mathrm{KWh} \mathrm{m}^{-2}$ day $^{-1}$ may be converted into $\mathrm{MJ} \mathrm{m}^{-2}$ day $^{-1}$ using a factor of 3.6 proposed by Hargreaves and Samani [14].

2.2. Empirical Model Based on Air Temperature. Hargreaves and Samani [14] were among the first to also suggest that the clearness index $R=G / G_{o}$ could be estimated using (5), given as

$$
\frac{G_{p}}{G_{o}}=\alpha \Delta T^{0.5},
$$

where $G_{p}$ and $G_{o}\left(\mathrm{MJ} \mathrm{m}^{-2}\right.$ day $\left.^{-1}\right)$ are as described by (1), $\Delta T(K)=T_{\max }-T_{\min }$, with $T_{\max }$ as the mean value of the daily maximum temperature, while $T_{\min }$ is the mean value of the daily minimum temperature, and $\alpha$ is a dimensionless empirical parameter, fixed at 0.16 for interior regions and 0.19 for coastal regions [2]. In order to account for the influence of altitude on $\alpha$, Allen [17] proposed an estimator for $\alpha$ using

$$
\alpha=\alpha_{a}\left(\frac{P}{P_{o}}\right)^{0.5},
$$

where $P$ and $P_{o}$ are the average atmospheric pressures at the altitude of the place and at sea level, respectively, and $\alpha_{a}$ was fixed at 0.17 for interior regions and 0.20 for coastal areas. In a later date, Chandel et al. [13] proposed a model, (7), based on (5) and (6) as

$$
\frac{G_{p}}{G_{o}}=7.9 \varphi^{-1}\left(\Delta T \sin \varphi\left(\frac{P}{P_{o}}\right)\right)^{0.5},
$$

where $\alpha_{a}$ from (6) has been expressed as a function of latitude, $\varphi$, in

$$
\alpha_{a}=7.9 \varphi^{-1}(\sin \varphi)^{0.5} .
$$

In this study we evaluated seven models, five of which were based on the Angstrom-Prescott relation [16], and two on the Hargreaves and Samani [14] models. These models with their values of the regression coefficients, $a$ and $b$ (Tables 1 and 2), have been proposed in the literature to be suitable for the estimation of global solar radiation on a horizontal surface in the tropics $[8,18]$. 
TABLE 1: Summary of the regression constants used by different authors in the tropics as well as that proposed by this paper, based on sunshine hours.

\begin{tabular}{|c|c|c|c|}
\hline Author & $a$ & $b$ & $\begin{array}{l}\text { Region of } \\
\text { application }\end{array}$ \\
\hline Turton (1987) [20] & 0.30 & 0.40 & Tropics \\
\hline Fagbenle (1990) [21] & 0.28 & 0.39 & Tropics \\
\hline $\begin{array}{l}\text { Otu-Danquah (1990) } \\
\text { [22] }\end{array}$ & 0.27 & 0.45 & Ghana (everywhere) \\
\hline $\begin{array}{l}\text { Jackson and Akuffo } \\
\text { (1992) [23] }\end{array}$ & 0.25 & 0.45 & Kumasi, Ghana \\
\hline $\begin{array}{l}\text { Augustine and } \\
\text { Nnabuchi }(2009 b) \\
{[18]}\end{array}$ & 0.29 & 0.42 & Tropics \\
\hline Proposed model & 0.22 & 0.43 & Kumasi, Ghana \\
\hline
\end{tabular}

2.3. Model Evaluation Schemes. The performances of the predictions of each model as against the measured values of the monthly means of daily solar radiations were assessed using fundamental error analysis schemes described by Muzathik et al. [9] and Maghrabi [19]. According to [9, 19], the mean percentage error (MPE), mean bias error (MBE), and root mean square error (RMSE) are given by the following equations:

$$
\begin{gathered}
\text { MPE }=\frac{1}{N} \sum_{i=1}^{N}\left(\frac{G_{i m}-G_{i p}}{G_{i m}} \times 100\right), \\
\text { MBE }=\frac{1}{N} \sum_{i=1}^{N}\left(G_{i p}-G_{i m}\right), \\
\text { RMSE }=\sqrt{\frac{I}{N}\left[\sum_{i=1}^{N}\left(G_{i p}-G_{i m}\right)^{2}\right]}
\end{gathered}
$$

where $G_{i m}$ is the $i$ th measured value, $G_{i p}$ is the $i$ th estimated or predicted value, and $N$ is the total number of observations. The MPE indicates the percentage deviation of the predicted and measured monthly average daily global solar radiation data. The MBE provides a clue to whether a given model has a tendency to under- or overpredict, with $\mathrm{MBE}$ values closest to zero being desirable. The RMSE on the other hand indicates the level of scatter that a model produces, thus providing a term-by-term comparison of the actual deviation between the predicted and observed values, with a lower RMSE value reflecting a better model in terms of its absolute deviation. The equations with the highest values of $R$ and $R^{2}$ and least values of MBE, RMSE, and MPE are suitable for predicting global solar radiation $[9,19]$.

\section{Results and Discussion}

Based on the Angstrom-Prescott model given in (1), it was observed that the clearness index was related to the fraction of sunshine hours by the constants $a=0.22$ and $b=$ 0.43 over the study area. With these derived approximated
TABLE 2: Summary of the regression constants used by different authors in the tropics as well as that proposed by this paper, based on air temperature measurements.

\begin{tabular}{lccc}
\hline Author & $a$ & $b$ & Model form \\
\hline $\begin{array}{l}\text { Hargreaves and } \\
\text { Samani (1982) [14] }\end{array}$ & 0.153 & -0.033 & $R=a(\Delta T)^{0.5}+b$ \\
Chandel et al. (2005) & 0.264 & -0.155 & $R=a \ln (\Delta T)+b$ \\
{$[13]$} & 0.311 & -0.293 & $R=a \ln (\Delta T)+b$ \\
Proposed & & &
\end{tabular}

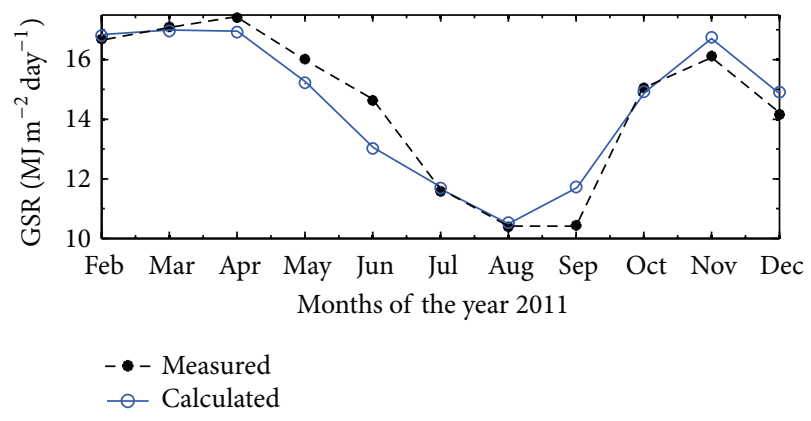

(a)

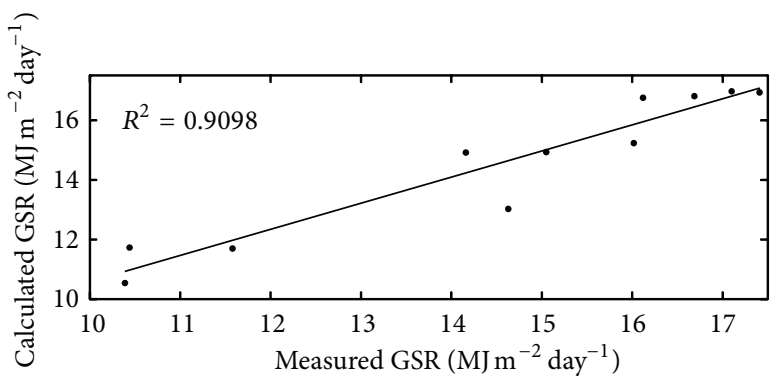

(b)

FIGURE 2: Comparison between the measured GSR and the calculated GSR using our proposed model.

constants, we proposed a model based on the AngstromPrescott model (1) and used it to calculate the monthly mean daily global solar radiation (GSR) for the study period and compared it with the measured values (Figure 2). The results showed that our proposed model was able to predict the variability of the monthly mean daily global solar radiation (Figure 2(a)) with a very high coefficient of determination of 0.9098 (Figure 2(b)).

The monthly comparison studies showed a very good agreement between the proposed model and the measurements with a $\mathrm{MBE}$ of -0.30 to -0.01 . In addition, the proposed model compared favourably well with the other empirical models used in the study. In most cases, the proposed models predicted the pattern of the measured solar radiation very well, especially the decrease in radiation between the months of May and August (Figure 2). The decrease in radiation could be attributed to the fact that these months constitute the rainy season, and hence the presence of clouds and rain droplets in the atmosphere prevented the surface from receiving more radiation. However, the other empirical 
TABLE 3: Summary of the model evaluations using sunshine hours.

\begin{tabular}{lccccc}
\hline Model form & $R$ & $R^{2}$ & $\left.\mathrm{MBE}_{(\mathrm{MJ} \mathrm{m}}^{-2} \mathrm{day}^{-1}\right)$ & $\mathrm{MPE}^{(\%)}$ & $\left.\mathrm{RMSE}_{(\mathrm{MJ} \mathrm{m}}{ }^{-2} \mathrm{day}^{-1}\right)$ \\
\hline Proposed & 0.9538 & 0.9098 & -0.0102 & 0.0585 & 0.0338 \\
Turton (1987) [20] & 0.9581 & 0.9179 & 2.4926 & -14.3170 & 8.2670 \\
Fagbenle (1990) [21] & 0.9578 & 0.9174 & 1.6177 & -9.2919 & 5.3654 \\
Otu-Danquah (1990) [22] & 0.9561 & 0.9142 & 2.1885 & -12.5706 & 7.2586 \\
Jackson and Akuffo (1992) [23] & 0.9553 & 0.9125 & 1.4688 & -8.4365 & 4.8715 \\
Augustine and Nnabuchi (2009b) [18] & 0.9575 & 0.9168 & 2.4430 & -14.0319 & 8.1024 \\
\hline
\end{tabular}

TABLE 4: Summary of the model evaluations using air temperature.

\begin{tabular}{lccccc}
\hline Author & $R$ & $R^{2}$ & $\mathrm{MBE}_{(\mathrm{MJ} \mathrm{m}}^{-2}$ day $\left.^{-1}\right)$ & $\mathrm{MPE}^{(\%)}$ & $\mathrm{RMSE}^{(\mathrm{MJ} \mathrm{m}}{ }^{-2}$ day $\left.^{-1}\right)$ \\
\hline Proposed & 0.9126 & 0.8328 & -0.2973 & 1.7075 & 0.9859 \\
Hargreaves and Samani (1982) [14] & 0.8822 & 0.7782 & 1.1709 & -6.7255 & 3.8835 \\
Chandel et al. (2005) [13] & 0.9149 & 0.8370 & 0.9409 & -5.4044 & 3.1206 \\
\hline
\end{tabular}

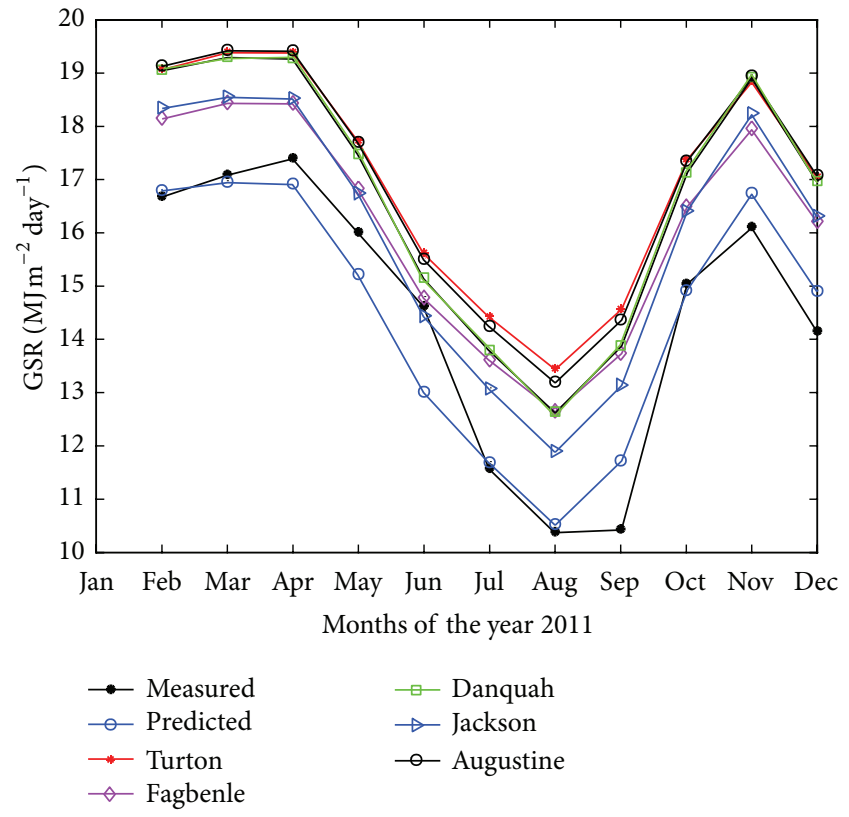

FIGURE 3: Measured and calculated GSR using the empirical models proposed in the literature as well as our proposed model (predicted).

models overestimated the measured global radiation between May and August (Figure 3). Nevertheless, the coefficient of determination found between the measured radiation and the proposed models was within acceptable values (see Table 3 for summary).

3.1. Determination of Global Solar Radiation from Air Temperature Measurements. Using the air temperature values from the study area, a model was developed based on that of Chandel et al. [13] (Table 2). Similarly our proposed model could predict the pattern of the measured monthly mean daily global solar radiation but underestimated them between the months of April-June and October-November while it overestimated the measured radiation for the months of

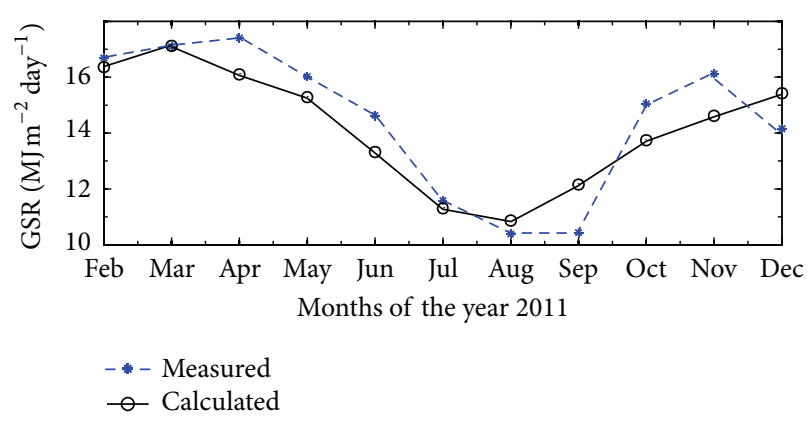

(a)

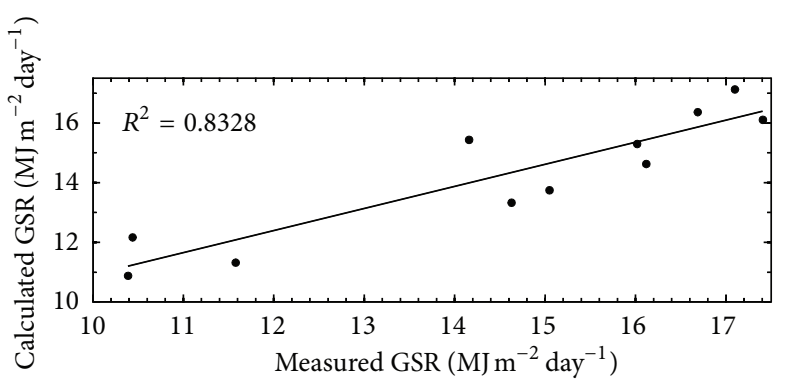

(b)

FIGURE 4: Comparison between the measured GSR and the calculated GSR using our proposed model (calculated).

August, September, and December (Figure 4(a)). The correlation between the measured and the predicted radiation gave a coefficient of determination $\left(R^{2}\right)$ of 0.8328 (Figure $4(\mathrm{~b})$ ).

In addition, a comparison between the measured values and those calculated using the proposed models by Hargreaves and Samani [14] and Chandel et al. [13], herein denoted as $G_{(\mathrm{H}-\mathrm{H})}$ and $G_{(\mathrm{Chen})}$, respectively (Figure 5), revealed that they predicted the pattern of the measured radiation very well. However, they overestimated the measured radiation in all the months except the months of April and November where the measured radiation were underestimated. Table 4 gives the summary of the correlation between the measured GSR and those calculated using $G_{(\mathrm{H}-\mathrm{H})}$ and $G_{(\mathrm{Chen})}$. 


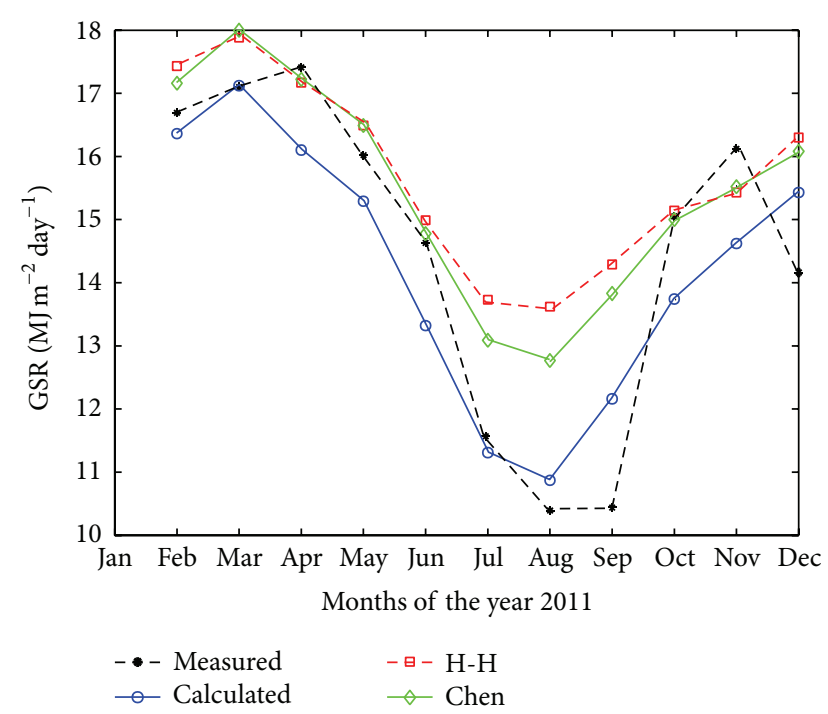

FIGURE 5: Comparison between measured GSR and the GSR calculated using the models by Chandel et al. [13] and Hargreaves and Samani [14] as well as our proposed model (calculated).

Summary of the model evaluations is given in Tables 3 and 4 for sunshine hours and air temperatures, respectively. The results showed that in both model evaluation methods, our proposed model, compared to the other models, displayed the smallest MBE, MPE and RMSE. This makes the proposed model most suitable for estimating global solar radiation. In the case of calculated GSR using sunshine hours, our model was followed by those proposed by Jackson and Akuffo [23], Fagbenle [21], Out-Danquah [22], Augustine and Nnabuchi [18], and Turton [20], respectively, in the order of performances (Table 3). While for the GSR calculated using air temperature, our proposed model was followed by those of Chandel et al. [13] and Hargreaves and Samani [14], respectively, in the order of performances (Table 4).

\section{Conclusions}

The performances of both sunshine and temperature dependent models for the estimation of global solar radiation (GSR) over Ghana and other tropical regions were evaluated and a comparison assessment of the models were carried out using measured GSR at Owabi in the Ashanti region of Ghana. Furthermore, we proposed two empirical models which also use sunshine hours and temperature measurements from the study site and its environs. The results showed that the models could predict very well the variability of the measured monthly daily mean global solar radiation for the entire period of the study. This could be attributed to the fact that the models used meteorological input data (sunshine hours and air temperatures) that also respond to the variability in atmospheric conditions such as rainfall, cloud cover, and the seasonal changes that affect the amount of solar radiation reaching the Earth's surface. Tables 3 and 4 provide the summary of the model evaluation results.
The results revealed that our proposed model using sunshine hours had the smallest values of MBE, MPE, and RMSE of $-0.0102,0.0585$, and 0.0338 , respectively (Table 3 ), while the proposed model using air temperature had MBE, MPE, and RMSE values of $-0.2973,1.7075$, and 0.9859, respectively, (Table 4). However, due to the fact that the sunshine hours data was measured from about $20 \mathrm{~km}$ from the study site, there is the possibility of discrepancies within the global solar radiation calculated from our sunshine input model, arising as a result of the difference in environmental conditions of the two areas (Owabi and Kumasi airport).

The comparison studies between the measured global solar radiation and the calculated global solar radiation suggest that both models can be employed to estimate monthly mean daily global solar radiation. However, the constants $a$ and $b$ as well as other meteorological input data for the models were found to be site specific, and therefore these models must be used with care for global solar radiation estimation. Currently, long term solar radiation measurements are being undertaken in other parts of Ghana that would be used in the near future to estimate the global solar radiation more accurately for effective use as a solar energy potential over the entire country.

\section{Conflict of Interests}

The authors declare that there is no conflict of interests regarding the publication of this paper.

\section{Acknowledgments}

The authors wish to acknowledge Mr. Elvis Kofi Agyapong who provided the field site technical support. The installation and maintenance of the automatic weather station at Owabi were funded by the EU project Quantifying Weather Impact on Health in Developing Countries (QWeCI, funded by the European Commission's Seventh Framework Research Programme under the Grant agreement 243964). The authors are also grateful to the reviewers for their comments and suggestions that contributed to improve this paper.

\section{References}

[1] E. O. Ogolo, "Evaluating the performance of some predictive models for estimating global solar radiation across varying climatic conditions in Nigeria," India Journal of Radio \& Space Physics, vol. 39, no. 3, pp. 121-131, 2010.

[2] K. K. Gopinathan, "Solar sky radiation estimation techniques," Solar Energy, vol. 49, no. 1, pp. 9-11, 1992.

[3] S. V. Tahâs, D. Ristoiu, and C. Cosma, "Trends of the global solar radiation and air temperature in Cluj-Napoca, Romania (19842008)," Romanian Journal in Physics, vol. 56, no. 5-6, pp. 784789, 2011.

[4] E. O. Falayi and A. B. Rabiu, "Estimation of global solar radiation using cloud cover and surface temperature in some selected cities in Nigeria," Archives of Physics Research, vol. 2, no. 3, pp. 99-109, 2011.

[5] E. Quansah, K. Preko, and L. K. Amekudzi, "First performance assessment of blends of jatropha, palm oil and soya bean 
biodiesel with kerosene as fuel for domestic purposes in ruralGhana," International Journal of Energy and Environment, vol. 2, no. 2, pp. 331-336, 2011.

[6] F. O. Akuffo, "Solar and wind energy resources assessment-final report," Preliminary Data Analysis and Evaluation, Vol. 1-2, a Consultant Report, The Ministry of Energy, Accra, Ghana, 1991.

[7] K. O. Afriyie, "Performance of Sayigh's universal formula in the estimation of global solar radiation in Ghana," Tech. Rep., International Centre for Theoretical Physics, Trieste, Italy, 1995.

[8] F. S. Arku, "The modelled solar radiation pattern of Ghana: its prospects for alternative energy source," Journal of African Studies and Development, vol. 3, no. 3, pp. 45-64, 2011.

[9] A. M. Muzathik, W. B. W. Nik, M. Z. Ibrahim, K. B. Samo, K. Sopian, and M. A. Alghoul, "Daily global solar radiation estimate based on sunshine hours," International Journal of Mechanical and Materials Engineering, vol. 6, no. 1, pp. 75-80, 2011.

[10] A. A. Trabea and M. A. M. Shaltout, "Correlation of global solar radiation with meteorological parameters over Egypt," Renewable Energy, vol. 21, no. 2, pp. 297-308, 2000.

[11] E. B. Pereira, F. R. Martins, S. L. Abreu et al., "Cross validation of satellite radiation models during SWERA project in Brazil," in Proceedings of the ISES Solar World Congress, pp. 14-19, Göteborg, Sweden, June 2003.

[12] M. J. Ahmad and G. N. Tiwari, "Solar radiation models-a review," International Journal of Energy Research, vol. 35, no. 4, pp. 271-290, 2011.

[13] S. S. Chandel, R. K. Aggarwal, and A. N. Pandey, "New correlation to estimate global solar radiation on horizontal surfaces using sunshine hour and temperature data for indian sites," Journal of Solar Energy Engineering, vol. 127, no. 3, pp. 417-420, 2005.

[14] G. H. Hargreaves and Z. A. Samani, "Estimating potential evapotranspiration," Journal of the Irrigation and Drainage Division, vol. 108, no. 3, pp. 225-230, 1982.

[15] R. G. Allen, L. S. Pereira, D. Raes, and M. Smith, "Crop evapotranspiration: guidelines for computing crop water requirements," Irrigation and Drainage Paper 56, Food and Agriculture Organisation of the United Nations (FAO), Rome, Italy, 1998.

[16] J. A. Prescott, "Evaporation from water surface in relation to solar radiation," Transactions of the Royal Society of Australia, vol. 46, pp. 114-118, 1940.

[17] R. Allen, "Evaluation of procedures for estimating mean monthly solar radiations from air temperature," Tech. Rep., Food and Agricultural Organisation of the United Nations (FAO), Rome, Italy, 1995.

[18] C. Augustine and M. N. Nnabuchi, "Correlation between sunshine hours and global solar radiation in Warri, Nigeria," Pacific Journal of Science and Technology, vol. 10, no. 2, pp. 574-579, 2009.

[19] A. H. Maghrabi, "Parameterization of a simple model to estimate monthly global solar radiation based on meteorological variables, and evaluation of existing solar radiation models for Tabouk, Saudi Arabia," Energy Conversion and Management, vol. 50, no. 11, pp. 2754-2760, 2009.

[20] S. M. Turton, "The relationship between total irradiation and sunshine duration in the humid tropics," Solar Energy, vol. 38, no. 5, pp. 353-354, 1987.

[21] R. O. Fagbenle, "Estimation of total solar radiation in Nigeria using meteorological data," Nigerian Journal of Renewable Energy, vol. 1, pp. 1-10, 1990.
[22] K. A. Otu-Danquah, "Associate Programme Officer, Ghana Energy Commission, P.M.B. Ministries, Accra,Ghana," Private Conversation, 1990.

[23] E. A. Jackson and F. O. Akuffo, "Correlations between monthly average daily global irradiation and relative duration of sunshine at Kumasi," Energy Conversion and Management, vol. 33, no. 1, pp. 13-22, 1992. 


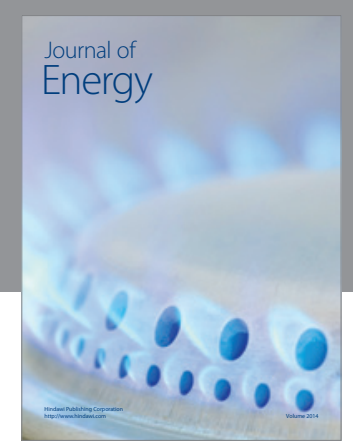

Journal of

Industrial Engineering
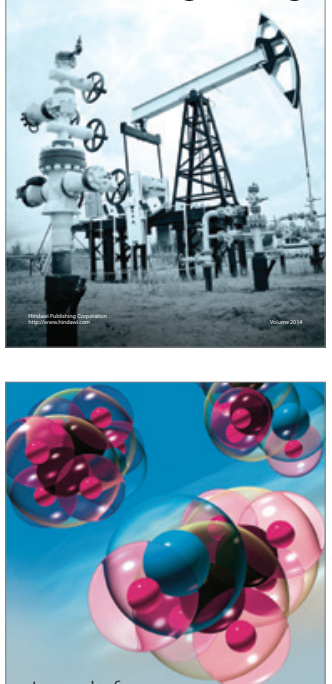

Fuels
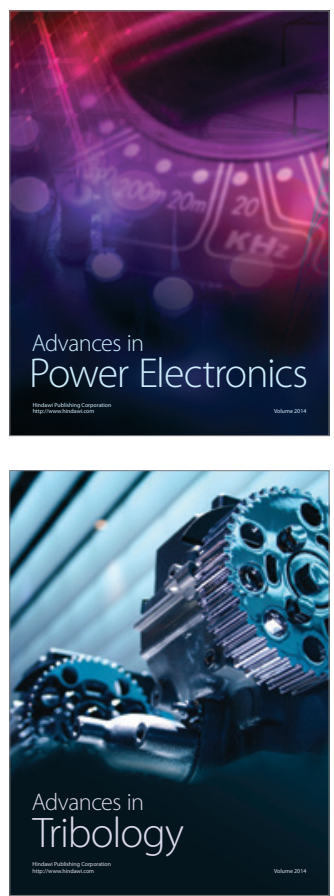

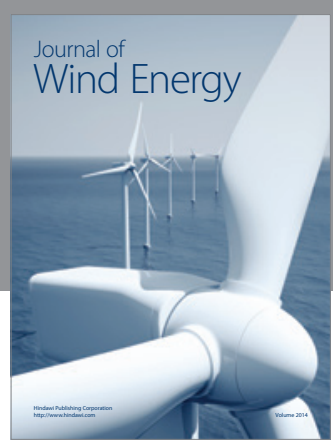

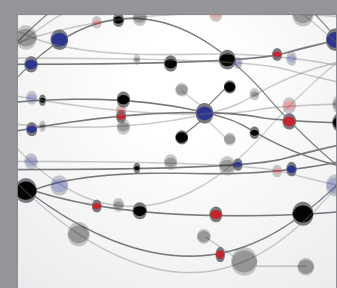

The Scientific World Journal

Submit your manuscripts at http://www.hindawi.com

Journal of

Structures
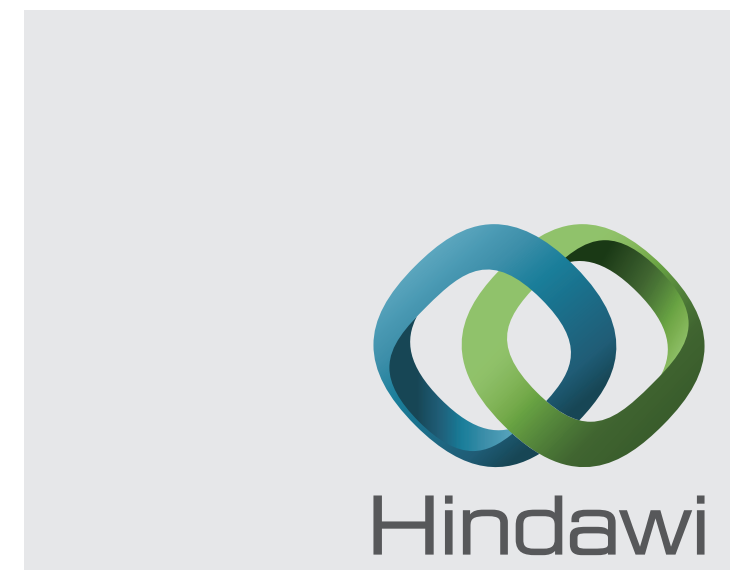

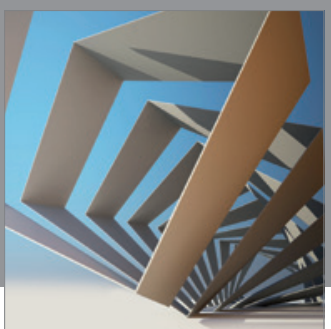

Rotating

Machinery
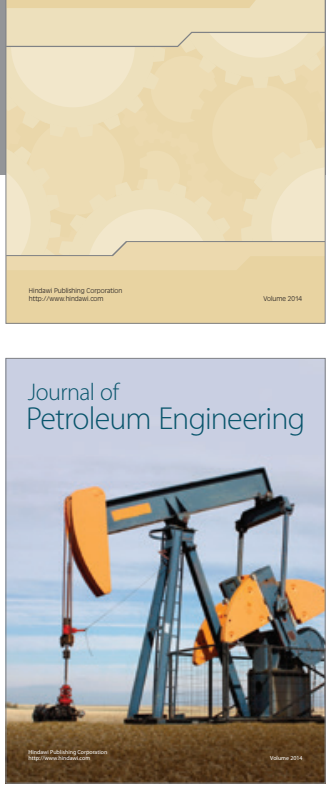

Journal of

Solar Energy
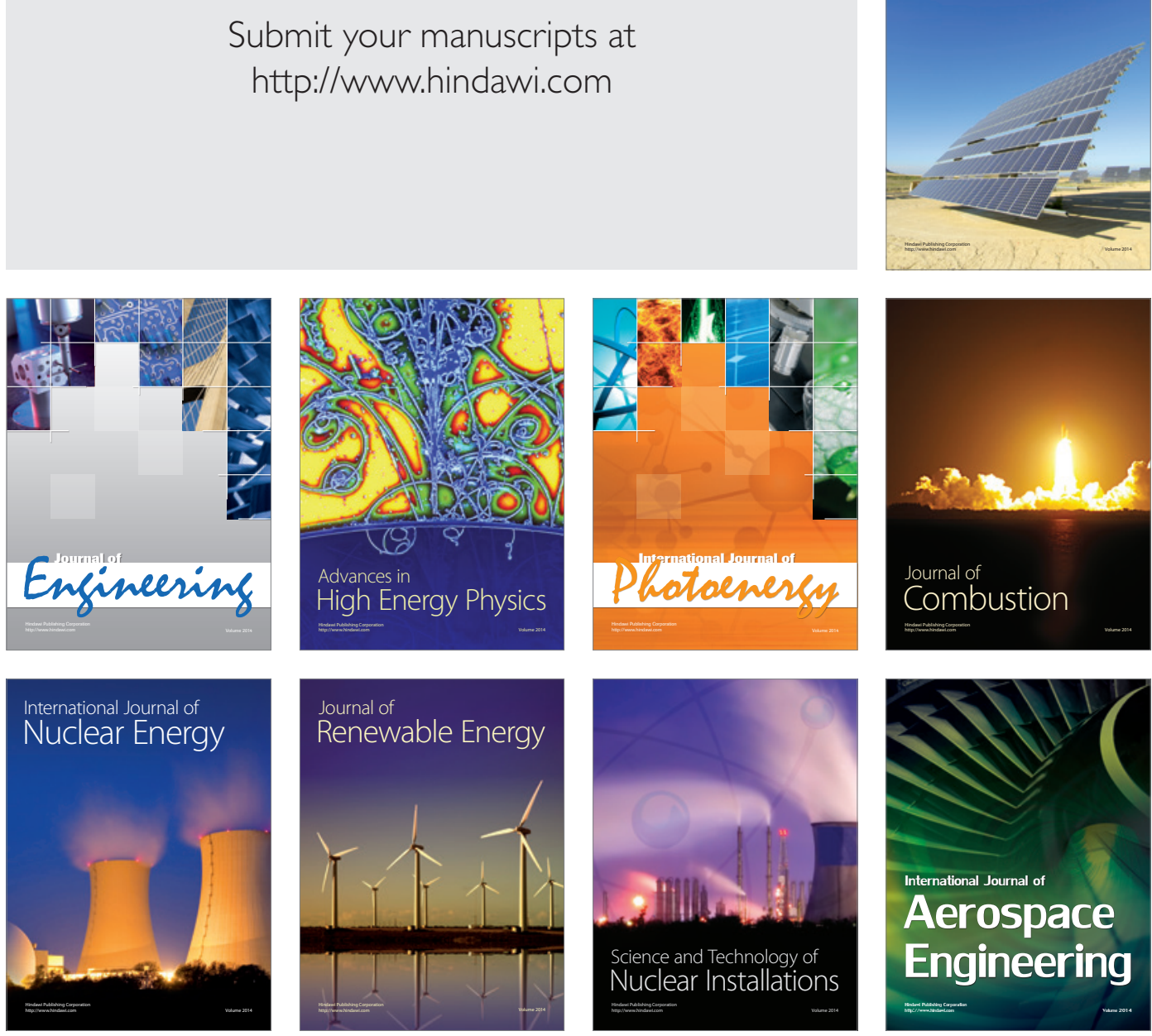